\title{
SISTEM PENDUKUNG KEPUTUSAN PENENTUAN PENILAIAN KARYAWAN BERPRESTASI MENGGUNAKAN METODE SAW DAN AHP
}

\author{
Merri Parida ${ }^{1}$, Achmad Benny Mutiara ${ }^{2}$ \\ ${ }^{1}$ Dosen Sistem Informasi, STMIK Dian Cipta Cendikia Lampung \\ ${ }^{1}$ E-mail: merriparida27@gmail.com, \\ ${ }^{2}$ Dosen Ilmu Komputer, Universitas Guna Darma \\ 2E-mail: amutiara@gmail.com
}

\begin{abstract}
ABSTRAK
STAI Ibnu Rusyd kotabumi adalah sebuah perguruan tinggi yang selalu berupaya dalam peningkatan mutu internal secara berkelanjutan agar dapat bersaing dengan perguruan tinggi swasta lain. Salah satu upaya yang dilakukan adalah dengan melakukan penilaian terhadap karyawan. Penilaian tersebut dilakukan untuk mengetahui karyawan berprestasi, akan tetapi penilaian karyawan yang dilakukan selama ini masih menggunakan metode manual. Berdasarkan kondisi tersebut maka diperlukan adanya metode yang tepat dan akurat dalam mengelola data penilaian karyawan.

Menggunakan metode Simple Additive Weighting (SAW) dengan Analytic Hierarchy Process (AHP) di hitung nilai masing-masing karyawan yang melibatkan beberapa kriteria yaitu kriteria komitmen, manajemen, kerjasama dan hasil kerja setelah perhitungan dilakukan maka ditentukan manakah metode yang paling tepat.

Dari penelitian ini dapat disimpulkan bahwa metode Analytic Hierarchy Process (AHP) lebih tepat untuk studi kasus pemilihan karyawan berprestasi karena pemilihan karyawan berprestasi ini melibatkan banyak subkriteria, dimana AHP dianggap tepat untuk mewakili pemikiranalamiah yang cenderung mengelompokkan elemen sistemke level-level yang berbeda dari masing-masing level berisi elemen yang serupa dan juga menyediakan skala pengukuran.
\end{abstract}

Kata Kunci- Sistem Pendukung Keputusan, Penilaian Karyawan Berprestasi, Simple Additive Weighting (SAW), Analytic Hierarchy Process (AHP)

\section{ABSTRACT}

STAI Ibnu Rusyd Kotabumi is a college that is always working in the internal quality improvement on an ongoing basis in order to compete with other private colleges. One of the efforts is to conduct an assessment of the employee. The assessment is conducted to determine the outstanding employee, but the employee assessment conducted so far still using manual methods. Under these conditions it is necessary to methodically and accurately manage employee appraisal data.

Using Simple Additive weighting method (SAW) with the Analytic Hierarchy Process (AHP) in calculating the value of each employee that involves several criteria commitment criteria, management, cooperation and the work after the calculation is then determined Which most appropriate method.

From this study it can be concluded that the Analytic Hierarchy Process (AHP) is more appropriate for the case study election performing employees for election performing employees involves many sub-criteria, which AHP is considered appropriate to represent the thought naturally that tends to group elements of the system to levels different of each level contains elements that are similar and also provides a measurement scale.

Keywords-Decision Support Systems, Employee Assessment Achievement, Simple Additive Weighting (SAW), Analytic Hierarchy Process (AHP) 